Annals of Warsaw University of Life Sciences - SGGW

Land Reclamation No 45 (2), 2013: 169-181

(Ann. Warsaw Univ. of Life Sci. - SGGW, Land Reclam. 45 (2), 2013)

\title{
Small strain stiffness in overconsolidated Pliocene clays
}

\author{
KATARZYNA MARKOWSKA-LECH, MARIUSZ LECH, MAREK BAJDA, \\ ALOJZY SZYMAŃSKI \\ Department of Geotechnical Engineering, Warsaw University of Life Sciences - SGGW
}

\begin{abstract}
Small strain stiffness in overconsolidated Pliocene clays. A huge development of technical infrastructure, including the construction of many high-rise buildings, roads, railroads and extension of subway lines, took place over the recent years in Poland. Therefore, numerous planned investment projects require geotechnical data documenting the variation of soil parameters found in the subsoil. The shear wave velocity is one of the most important input parameters to represent the stiffness of the soil deposits. This paper focuses on the methods and devices using measurements of the shear wave velocity to estimate the initial shear modulus in cohesive soil. It is preferable to measure $V_{S}$ by in situ wave propagation tests, however it is often economically not feasible in all regions of Poland. Hence, a reliable correlation between shear wave velocity and parameters measured in triaxial cell or static penetration parameters would be a considerable advantage. This study shows results obtained from the bender elements tests and field techniques seismic cone penetration test and seismic flat dilatometer, performed on overconsolidated cohesive soils in Warsaw. On the basis of the test results possible correlations between shear wave velocity (initial shear modulus), mean effective stress and void ratio are considered and four original empirical relationships are proposed. Moreover, the proposed formulas by two different techniques using triaxial apparatus and also RCPT cone were examined. The proposed formulas show a reasonable agreement with direct shear wave velocity profiles for clays and might be incorporated into routine laboratory and field practice.
\end{abstract}

Key words: shear wave velocity, bender element test, in situ wave propagation test, overconsolidated clays

\section{INTRODUCTION}

For the accurate prediction of the settlement of foundation it is required to conduct the deformation tests. The oedometer test, standard penetration test (SPT), cone penetrometer test (CPTU), and dilatometer test (DMT) are commonly used for shallow foundation design. To provide higher level of services, more sophisticated subsurface investigations that accurately quantify the soils deformation properties have to be performed.

In recent years, there has been an increasing interest in describing the mechanical behaviour of soils at small strain. The shear modulus $\left(G_{0}\right)$ at very small strain (initial shear modulus) is widely considered to be a fundamental soil stiffness property, as well as it is significant parameter applied in geotechnical case studies, and it is important in practical geotechnical solutions, particularly in the prediction of soil structure interaction and earthquake engineering (Arulanthan et al. 1998, LoPresti et al. 1999a, LoPresti et al. 1999b, Nash et al. 1999, Kuwano et al. 2000, Schnaid 2005, Stokoe et al. 2005). Hardin and Black (1968) identified major factors, which contribute to the actual value of the shear modulus such as vertical effective stress, void ratio, OCR, soil fabric, temperature, degree of saturation. 
Recently, most developed techniques, which are represented by combination of standard geotechnical tests with geophysical module (shear wave velocity measurement) have been used both in the laboratory and in situ conditions. The field techniques include here: seismic cone penetration test, seismic flat dilatometer, crosshole tests and SASW (MASW) method. The laboratory tests are represented by resonant column, torsional shear and triaxial tests with local strain measurement and bender element test. Such configurations diminish disadvantages of each group of tests and considerable enhance the optimization of data collection (Wolski and Lipinski 2006). In the present paper the results obtained from the bender elements, SCPT and SDMT tests are presented.

It is possible to obtain the initial shear modulus of the soil at induced strain levels less than $0.0001 \%$ from shear wave velocity according to the following equation:

$$
G_{0}=\rho \cdot V_{S}^{2}
$$

where:

$G_{0}$ - shear modulus,

$\rho$ - mass density,

$V_{S}$ - velocity of shear waves for linear, elastic and isotropic medium.

The powerful equation for calculating the initial shear modulus, originally proposed for sands (Hardin and Blanford 1989) also applies to clayey soils:

$$
\begin{aligned}
& G_{0(i j)}=S_{(i j)} \cdot F(e) \cdot(O C R)^{k} . \\
& \cdot p_{a}{ }^{\left(1-n_{i}-n_{j}\right)} \cdot\left(\sigma_{i}\right)^{n_{i}} \cdot\left(\sigma_{j}\right)^{n_{j}}
\end{aligned}
$$

where:

$S_{i j}$ - non-dimensional material constant reflecting the soil's fabric,

$F(e)$ - void ratio function,

$p_{a}$-atmospheric pressure,

$\sigma_{i}, \sigma_{j}$ - effective normal stresses in the $i$ - and $j$-directions,

OCR - overconsolidation ratio,

$k$-empirical function dependent on the plasticity index of clay, $k=0$ when $P I$ $<40$ and $k=1$ when $P I>40 ; p_{r}$ - references stress, $p_{r}=1 \mathrm{kPa} ; n_{i}, n_{j}$ - empirical stress exponents.

Jamiolkowski et al. (1995) evaluated the constants for a number of clays, by using a void ratio function as follows:

$F(e)=e^{x}$

where:

$x=-1.3$ for clays and assuming that $n_{i} \approx n_{j}$ they showed that $k=0$.

Additionally, assuming the isotropic stress condition, equation (2) is simplified to:

$G_{0}=S \cdot F(e) \cdot\left(\sigma_{m}\right)^{\mathrm{n}}$

where:

$\sigma_{m}-$ mean stress.

The factors, which mostly affect the soil stiffness, are vertical and lateral effective stress and void ratio. Therefore, the influence of the soil overconsolidation is excluded. In the present paper the influence of soil overconsolidation is not taken into account.

\section{GEOLOGY OF THE STUDY AREA}

The investigated area lies within a regional geomorphologic unit called Warsaw Basin. The test sites was located in Warsaw in the Vistula River valley. 
The site investigation was conducted at two differently located research sites. The first one was Stegny site, where a large research program is carried out by the Faculty of Geology of the Warsaw University, Faculty of Civil and Environmental Engineering of the Warsaw University of Life Sciences and other research institution. The main purpose of investigations was the estimation of physical properties and mechanical parameters of Pliocene (Tertiary) clays. The Stegny site is located in the southern district of Warsaw. The stratigraphy consists of Quaternary deposits defined as fine and medium dense sand layers of thicknesses not exceeding $4.5 \mathrm{~m}$, underlain by overconsolidated (OCR between 5.6 and 7.8 in increasing order - DMT tests) Pliocene high plasticity clays $(\mathrm{CH})$.
The clay beds present a clear layered structure characterized by different color of the particular layers. The free groundwater table is located at a depth of $3.2 \mathrm{~m}$ (Figure 1). Six undisturbed core samples (S1 to S6) of Pliocene clays from depths between 13 and $20 \mathrm{~m}$ under ground surface were obtained.

The second study area was located in Bielany in the northern part of Warsaw. The soil profile of Bielany site is shown in Figure 1. The stratigraphy consists of a $2.0 \mathrm{~m}$ sand layer underlain by clayey sand (SC) about $8.0 \mathrm{~m}$ thicknes overlying a layer of sandy clay $(\mathrm{OCR}=5.2-5.6$ from DMT tests and being approximately constant with depth) of low plasticity (CL) extending to a depth below $23 \mathrm{~m}$. The water table level stabilizes at depths from ca. $4 \mathrm{~m}$ to ca. $6.3 \mathrm{~m}$ below ground
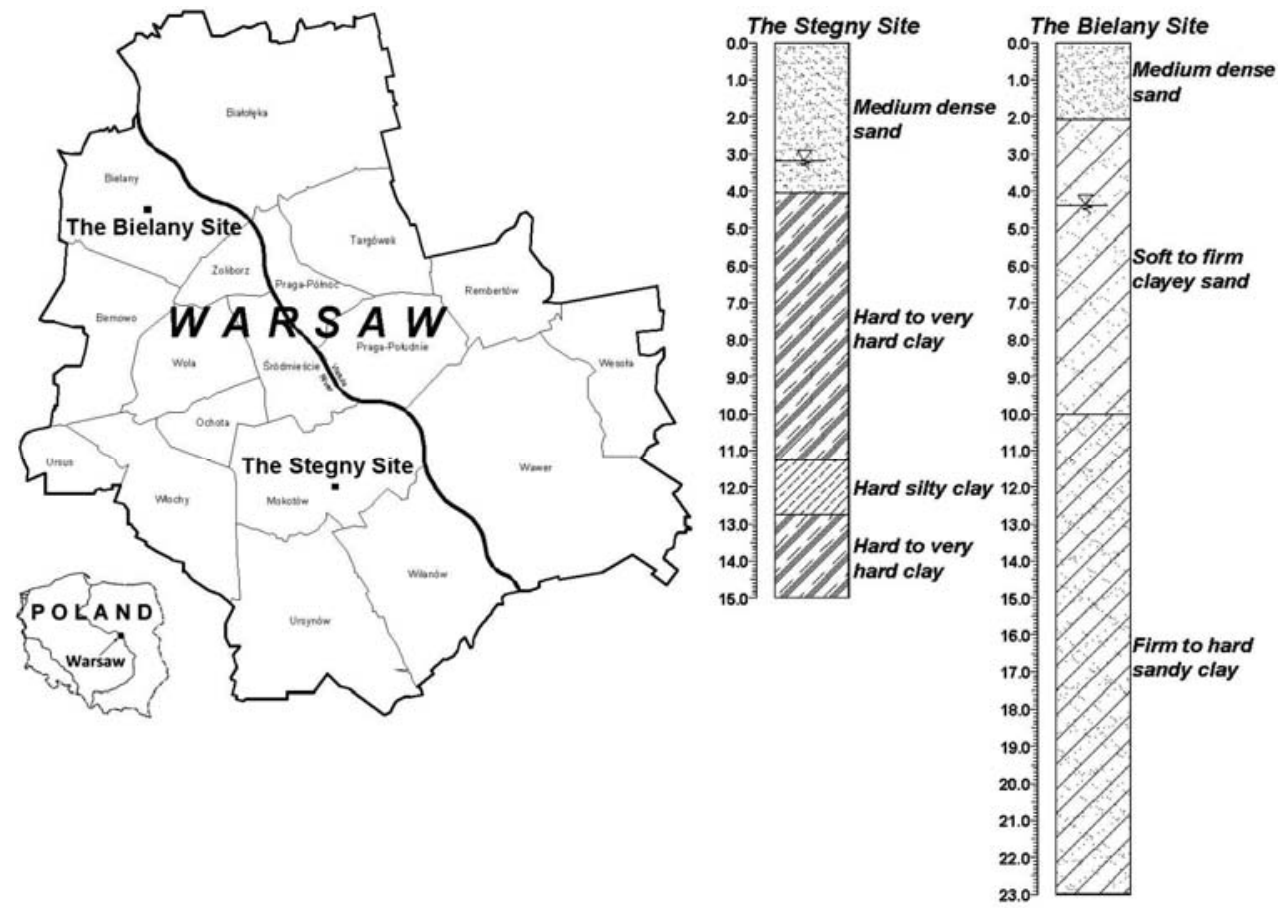

FIGURE 1. Locations and the subsurface conditions of the test sites 
surface. Four undisturbed core samples (S7 to S10) for laboratory testing were obtained from low plasticity clay (CL) layer.

\section{LABORATORY AND FIELD MEASUREMENTS}

\section{Bender Element Test}

To obtain the relationship between the shear wave velocity, effective stress and void ratio in the laboratory, the triaxial tests were performed on 25 clay and sandy clay specimens (10 core samples were divided into 25 specimens). The physical properties of selected specimens are presented in Table 1. in more reliable deformation characteristics were obtained during consolidation and shearing stage of the test. The bender elements are small electro-mechanical transducers, which either bend as an applied voltage is changed or generate voltage as they bend. The bender elements were placed into soil samples during the triaxial tests. The change of voltage applied to the transmitter caused a bend and transmition of a shear wave through the sample; the transmission of the shear wave at the other end of the sample was recorded by the receiver as a change of voltage (Viggiani 1995, Brignoli et al. 1996, Kawaguchi et al. 2001).

The triaxial tests were performed in three stages: saturation (back pressure

TABLE 1. Index properties of selected soil specimens

\begin{tabular}{|l|l|l|c|c|c|c|c|}
\hline No & Soil (Classification) & Location & $\begin{array}{c}\text { Depth } \\
{[\mathrm{m}]}\end{array}$ & $\begin{array}{c}\text { Fines } \\
\text { content } \\
{[\%]}\end{array}$ & $\begin{array}{c}\text { Water } \\
\text { content } \\
w_{n} \\
{[\%]}\end{array}$ & $\begin{array}{c}\text { Plasticity } \\
\text { index } \\
{[\%]}\end{array}$ & $\begin{array}{c}\text { Liquidity } \\
\text { index [-] }\end{array}$ \\
\hline S1 & Clay (CH) & Stegny & $15.0-15.6$ & 52 & 24.1 & 47.1 & 0.05 \\
\hline S2 & Clay (CH) & Stegny & $13.1-13.7$ & 56 & 32.5 & 47.1 & 0.05 \\
\hline S3 & Clay (CH) & Stegny & $17.5-18.0$ & 50 & 29.0 & 44.5 & 0.05 \\
\hline S4 & Clay (CH) & Stegny & $19.5-20.0$ & 51 & 20.0 & 42.0 & -0.07 \\
\hline S5 & Silty clay (CH) & Stegny & $18.0-18.4$ & 38 & 21.7 & 41.0 & 0.07 \\
\hline S6 & Clay (CH) & Stegny & $16.0-16.5$ & 53 & 23.9 & 36.0 & -0.20 \\
\hline S7 & Sandy clay (CL) & Bielany & $22.5-23.0$ & 28 & 21.5 & 26.6 & 0.09 \\
\hline S8 & Sandy clay (CL) & Bielany & $21.5-22.0$ & 25 & 17.4 & 25.1 & -0.01 \\
\hline S9 & Sandy clay (CL) & Bielany & $14.0-14.5$ & 17 & 22.5 & 18.3 & 0.21 \\
\hline S10 & Sandy clay (CL) & Bielany & $17.0-17.5$ & 22 & 21.5 & 18.3 & 0.20 \\
\hline
\end{tabular}

The triaxial tests were performed in a cell with internal linking bars, which enables easy access to a specimen at each stage of its preparation, and aditionally it was also equipped with bender elements located at the top and the bottom platens. This type of cell results also method), consolidation and shearing (strain controlled mode with strain rate $0.005 \mathrm{~mm} / \mathrm{min}$ ). The consolidation of samples was performed in the isotropic stress condition, 13 samples in drained and 12 in undrained conditions. The measurements of the shear wave velocity 
were performed at the end of each saturation and consolidation stages during triaxial tests. A wave signal was generated using the signal wave generator in the transmitter bender element. For a better interpretation of the transmission time, a sine wave pulse was used at the same stress condition and with different frequencies of the input signals (Markowska-Lech 2006, Markowska-Lech et al. 2007) as proposed by Viggiani (1995). A typical receiver signals obtained from the bender element test are presented in Figure 2. geophones - transmission time from $1^{\text {st }}$ (upper) to the $2^{\text {nd }}$ (lower) geophone, $h$-distance between transmitter and receiver - geophones (the effective wave transmission path through the sample; $1 \mathrm{~m}$ in case of SCPT and $0.5 \mathrm{~m}$ in SDMT test).

The initial shear modulus was calculated from equation (1).

\section{Downhole Test}

In order to obtain $V_{S}$ profile in the field the seismic surveys have been conducted. The downhole tests using SCPT cone at

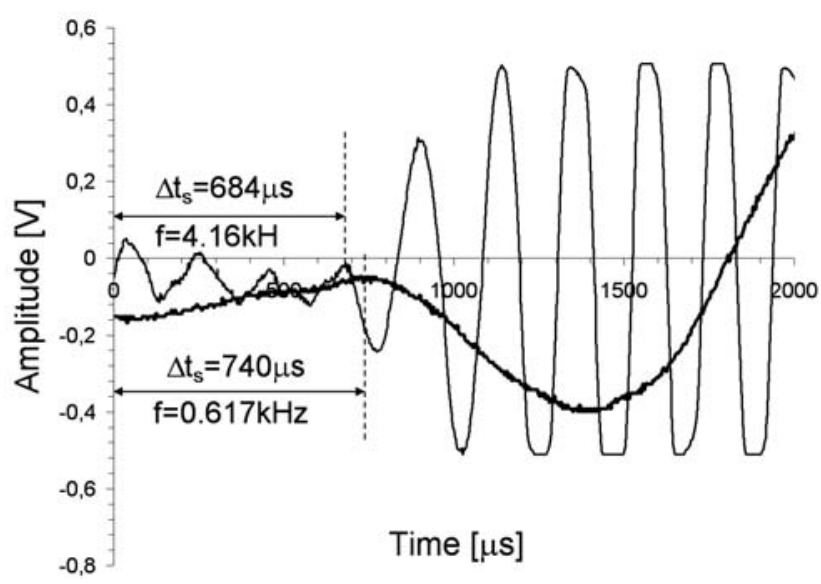

FIGURE 2. Typical receiver signals obtained from bender element test at different frequencies of transmitted signals and the same effective stress $(30 \mathrm{kPa})$

The velocity of the shear wave $\left(V_{S}\right)$ was calculated from the ratio of tip-to-tip distance between the transmitter and receiver using the fundamental relationship:

$$
V_{S}=\frac{h}{t}
$$

where:

$V_{\mathrm{S}}$ - shear wave velocity,

$t$ - transmission time of seismic waves between the transmitter and the receiver (in case of SCPT and SDMT with two the Stegny site and seismic flat dilatometer (SDMT) at the Bielany site were applied in this study. The research was carried out on heavily overconsolidated sandy clays and high plasticity clays.

The SCPT cone is additionally equipped with two geophones located at the distance of $1 \mathrm{~m}$ which enable measurement of the shear wave velocity in one-meter layer. During each SCPT test the cone penetration is stopped every $1 \mathrm{~m}$, so the shear wave of the ground 
surface can be generated. When the impulse approaches the upper geophone, the oscilloscope switches on and the impulse transmitting to the lower geophone is recorded. The transmission time obtained from the oscilloscope readings and the measured distance between geophones allow the estimation of the shear wave velocity.

The seismic dilatometer is the combination of the traditional flat dilatometer with a seismic module placed above the blade. The SDMT module is a probe equipped with two geophones of a $0.5 \mathrm{~m}$ spacing. The SDMT procedure for obtaining the shear wave velocity is the same as in SCPT probe. The signals obtained from SDMT test are shown in Figure 3.

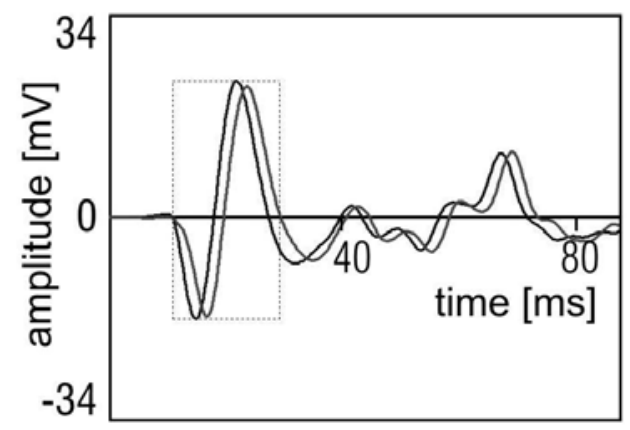

FIGURE 3. Typical receiver signals obtained from SDMT test

The values of the shear wave velocity in high plasticity clays at the Stegny site measured by SCPT cone vary from 150 to $200 \mathrm{~m} / \mathrm{s}$. The results in sandy clays at the Bielany site measured by SDMT vary between 270 and $320 \mathrm{~m} / \mathrm{s}$. It appears that in the sandy clay deposits the values of the shear wave velocity are slightly higher because of the higher content of the sand particles. The shear modulus $G_{0}$ calculated according to elastic theory is in the range of from ca. 45 to $90 \mathrm{MPa}$ in clays (Stegny) while in sandy clays (Bielany) it exceeds $150 \mathrm{MPa}$. The result of measurements are given in the next paragraph.

\section{BENDER ELEMENT TEST RESULTS}

The results obtained in laboratory from the bender element tests are presented in Figures 4, 5 and 6. Figures 4 and 5 ilustrate the collected data versus mean effective stress and void ratio. The values of shear wave velocity vary from 100 to $300 \mathrm{~m} / \mathrm{s}$ in applied mean effective stress of the range between 15 and $500 \mathrm{kPa}$. The increase of mean effective stress during the next stage of the consolidation causes a decrease of void ratio and as a result it gives the increase of the shear wave velocity.

The average trends are also obtained and it could be noted that there is a linear relationship between the mean effective stress and the shear wave velocity at very small strains $\left(\mathrm{R}^{2}\right.$ for the trend lines is between 0.82 and 0.96). Moreover, the largest increase of the value of the shear wave velocity was observed for samples S9 and S7 and the smallest one for sample S10 (CL - sandy clays from the Bielany site). It is probably due to a higher sand fraction content and differences between sandy clays specimens. In case of high plasticity clays the trend lines are similar.

The shear modulus at very small strain calculated in laboratory from equation (1) in tested clays and sandy clays does 


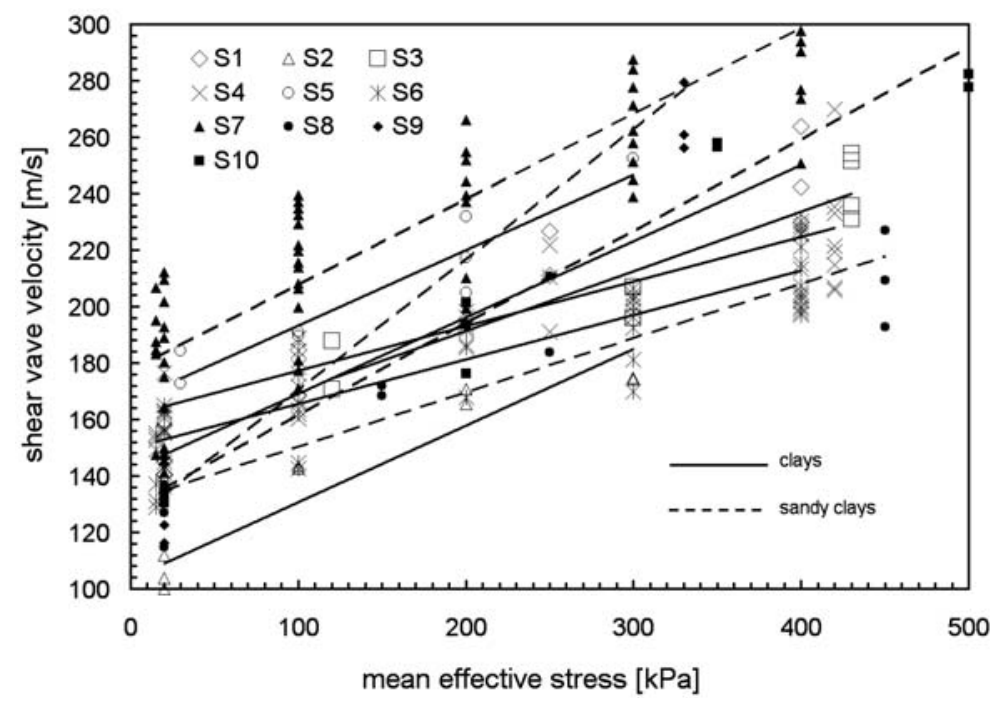

FIGURE 4. Shear wave velocity versus mean effective stress in clayey deposits tested in laboratory

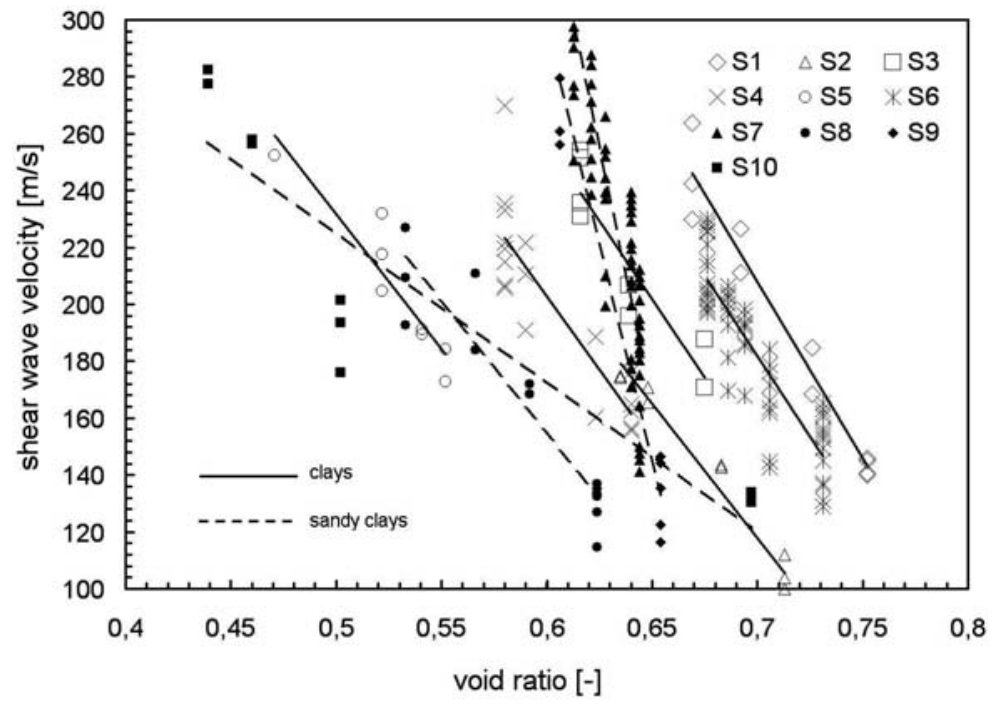

FIGURE 5. Shear wave velocity versus void ratio in clayey deposits tested in laboratory

not exceed $200 \mathrm{MPa}$. These values, based effective stress and void ratio. The folon elastic theory, are shown in Figure $6 . \quad$ lowing relationship suggested for clays

The tests results indicated the pos- is helpful in estimating the shear modusibility of estimation of the initial shear lus at very small strain without the shear modulus in cohesive soils based on mean wave velocity measurement: 


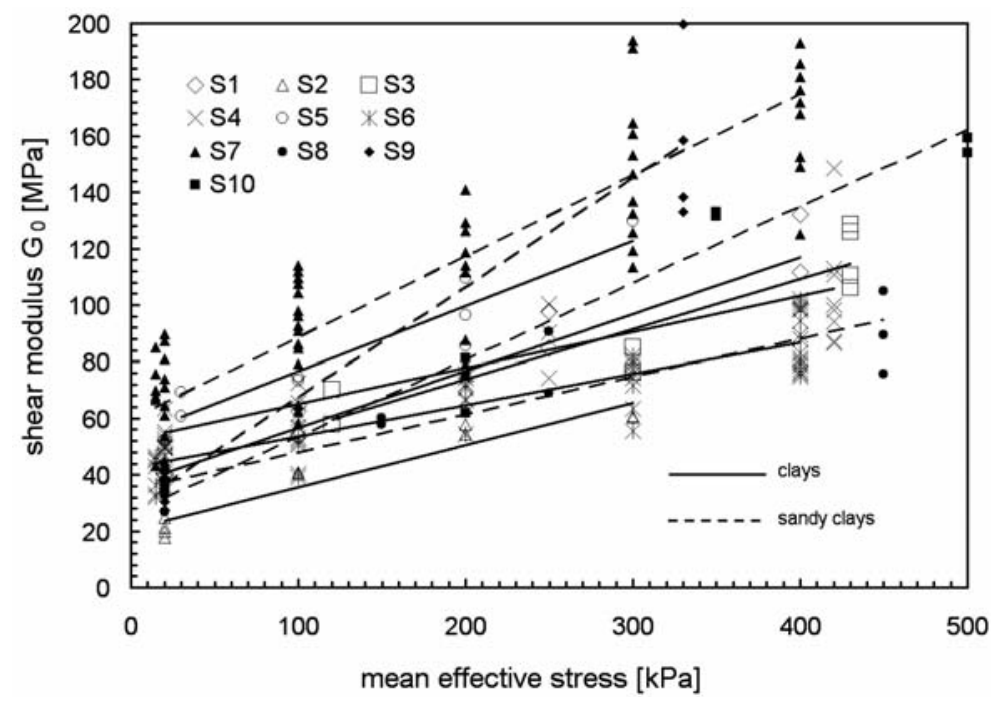

FIGURE 6. Variation of shear modulus with mean effective stress

$$
V_{S}=91.13 \cdot p^{, 0.11} \cdot e^{-0.61}
$$

where:

$V_{s}-$ shear wave velocity,

$p^{\prime}$ - mean effective stress in $\mathrm{kPa}$, $e-$ void ratio.

The correlation $(\mathrm{R})$ between the values calculated from the relationship in equation (6) and the results of laboratory tests is about $84 \%$ and mean relative error (MRE) is $8 \%$. Similarly, the relationship between the shear modulus, mean effective stress and void ratio could be expressed as the following equation:

$G_{0}=14.24 \cdot p^{, 0.23} \cdot e^{-1.26}$
In this case, the correlation is as good as in the equation (6) $-84 \%$, but the mean relative error is twice greater $(16 \%)$. Therefore, for tested soils it is probably better to estimate the shear wave velocity from equation (6) and then to find the shear modulus from the elastic theory than to estimate it directly from equation (7). The coefficients of statistical formulas (6) and (7) suggested for high plasticity clays and generally including all clayey deposits, are presented in Table 2.

TABLE 2. Proposed expressions for two categories of clayey deposits

\begin{tabular}{|l|l|c|c|c|c|c|}
\hline \multicolumn{2}{|l|}{ Equation } & $\alpha_{0}$ & $\alpha_{1}$ & $\alpha_{2}$ & $\begin{array}{c}\mathrm{R} \\
{[\%]}\end{array}$ & $\begin{array}{c}\mathrm{MRE} \\
{[\%]}\end{array}$ \\
\hline \multirow{2}{*}{$V_{s}=\alpha_{0} \cdot p^{, \alpha_{1}} \cdot e^{\alpha_{2}}$} & Clays (high plasticity) & 91.13 & 0.11 & -0.61 & 83.67 & 7.7 \\
\cline { 2 - 7 } & Clays (global) & 125.86 & 0.15 & -0.46 & 83.65 & 12.1 \\
\hline \multirow{2}{*}{$G_{0}=\alpha_{0} \cdot p^{, \alpha_{1}} \cdot e^{\alpha_{2}}$} & Clays (high plasticity) & 14.24 & 0.23 & -1.26 & 83.86 & 16.03 \\
\cline { 2 - 7 } & Clays (global) & 34.99 & 0.34 & -1.06 & 86.04 & 27.0 \\
\hline
\end{tabular}




\section{VALIDATION OF PROPOSED FORMULAS}

The purpose of this study was to explore the variation of $V_{S}$ with stress and void ratio. In order to verify the method of $V_{S}$ calculation proposed in present study, eight core samples from the Stegny site were taken and tested in the laboratory. The samples were taken from the location close to the previous borehols from the depth between 6 and $15 \mathrm{~m}$ using the same Shelby sampler. The shear wave velocity and shear modulus obtained from standard triaxial apparatus (mean effective stress and void ratio) and calculated from proposed formulas are shown in Figures 7 and 8. Figures show that the values of shear wave velocity and the shear modulus increase rapidly as the mean effective stress is growing. All points demonstrate a very similar values to those from bender element test.

Due to the soil variability associated with its depositions, the most reliable method to obtain $V_{s}$ is a direct in situ measurement. Based on the above, the values of calculated shear wave velocity were compared against those obtained from the in situ seismic tests. The proposed formula was examined by three different techniques using triaxial apparatus (TXT), RCPT cone and also by calculating it using particle density and moisture content obtained for core samples.

The shear wave velocity profile from SDMT test at Bielany site is shown in Figure 9. Comparing the shear wave velocities for sandy clays it appears that the new data points, based on the proposed formula, fit closely the shear wave velocities from the direct SDMT measurements. The in situ measured velocities are slightly lower than the calculated ones.

The comparison of the shear wave velocity directly measured by SCPT cone at the Stegny site and calculated from the new formula for high plasticity

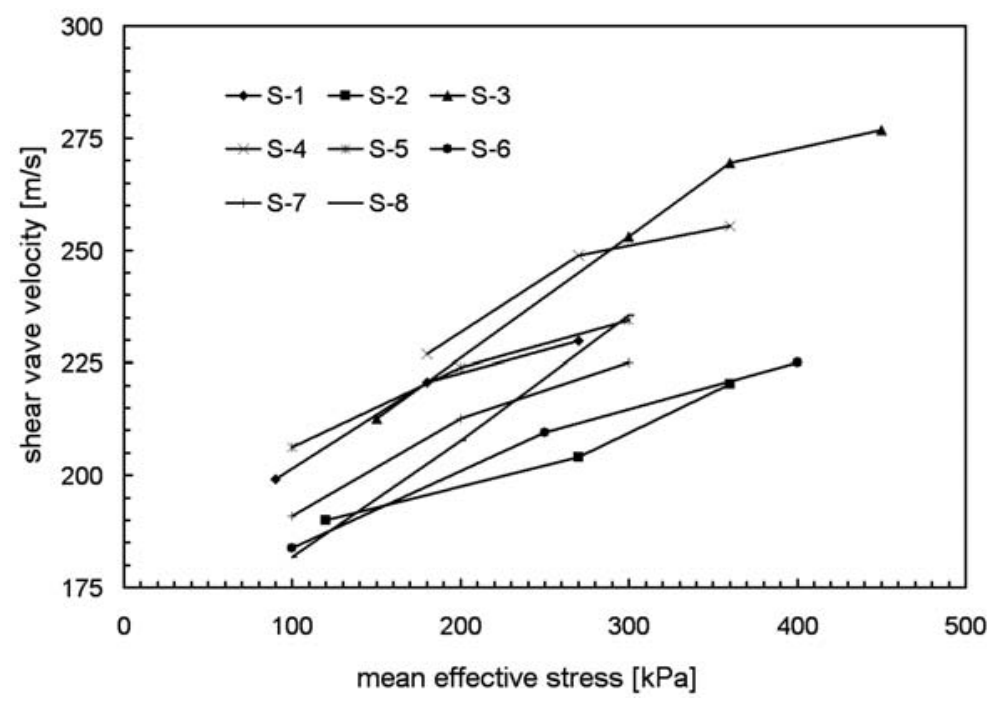

FIGURE 7. Shear wave velocity calculated according to new formula 


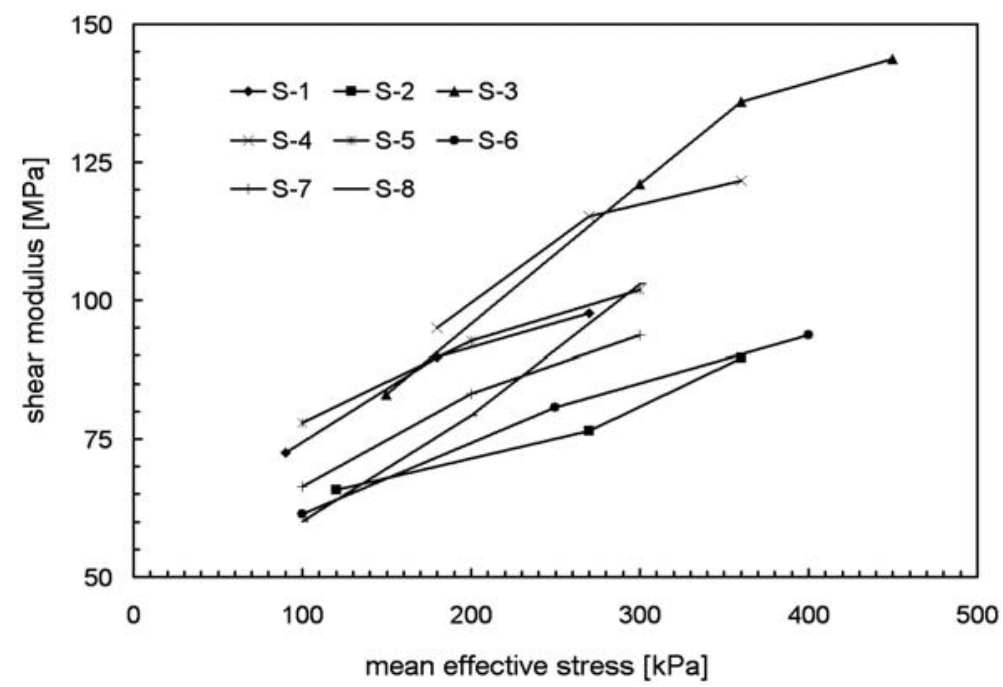

FIGURE 8. Initial shear modulus calculated according to new formula

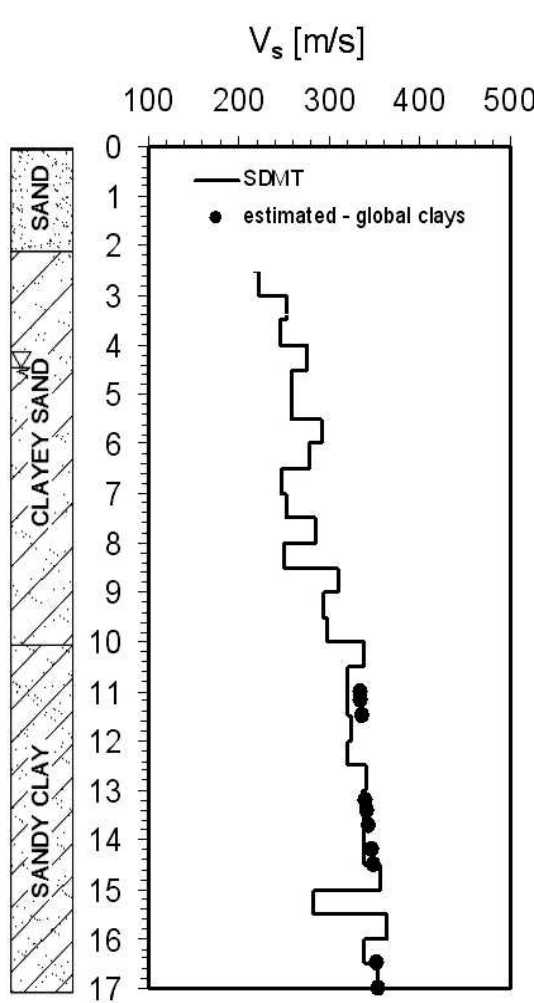

FIGURE 9. Comparison of $V_{S}$ profile obtained from SDMT test and predicted - the Bielany site clays is shown in Figure 10. The laboratory tests (TXT) and calculated $V_{S}$ values fit field data well. Comparisions with field $V_{S}$ data show a very poor match remote from the sample depth of $8.0 \mathrm{~m}$ and in this case the difference is $24 \%$. This variance between the calculated and the measured values of shear wave velocity is an effect of experimental or interpretative errors, different stress history and possible sample disturbance. The rest of data pionts show a reasonable agreement with direct shear wave velocity profiles for high plasticity clays $(\mathrm{CH})$.

In order to make further comparison between result obtained from SCPT tests and using new formula, the RCPTU test at the Stegny site was also done. The data obtained from RCPTU tests show generally a good agreement, with the exeption of the depth of about $12 \mathrm{~m}$, which were higher in the RCPTU test. The differencies in values of $V_{S}$ can be explained in terms of different values of void ratio in silty clay layer. As shown in Figure 10, 


\section{$\mathrm{V}_{\mathrm{s}}[\mathrm{m} / \mathrm{s}]$}

100125150175200225250275
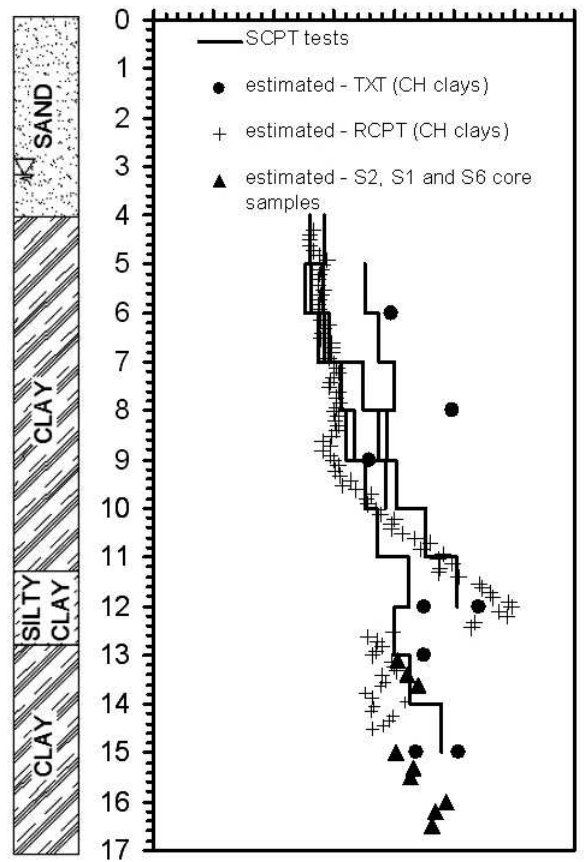

FIGURE 10. Comparison of $V_{S}$ profiles obtained from a series of SCPT tests and predicted from triaxial (TXT), RCPTU and soil core samples - the Stegny site

the shear wave velocity calculated using particle density and moisture content and obtained for core samples S1, S2 and S6 fits SCPT data well too.

\section{CONCLUSIONS}

In this study, possible correlations between the shear wave velocity (initial shear modulus), the mean effective stress and the void ratio were considered. It is possible to draw the following conclusions:

1) The mean effective stress and the void ratio have a visible influence on the shear wave velocity in tested clayey deposits. Based on laboratory tests, it can be noticed that there is linear relationship between the mean effective stress and the shear wave velocity at very small strains.

2) The proposed relationships are still a preliminary and need verification by being applied at different clay sites. Good correlations, obtained for equations in Table 2, allow the estimation of the shear wave velocity and the initial shear modulus according to the proposed empirical formulas.

3) The prediction of $V_{s}$ by proposed equations is in a good agreement with the directly measured values using SCPT and SDMT tests. However, the shear wave velocity and the initial shear modulus from in situ tests are slightly lower than those calculated from laboratory tests.

4) Although a good correlation between the shear wave velocity and the mean effective stress and the void ratio was obtained in tested soil, it is necessary to continue the investigations in order to examine the influence of the stress history on the shear modulus, especially in heavily overconsolidated cohesive soil.

5) The RCPT tests indicate that there is a good agreement between the shear wave velocities calculated and directly measured, but a precise evaluation of void ratio is required. The higher differences of the shear wave velocities for different sediments (clays and silty clays) is due to the variance of the void ratio calculated in in situ conditions.

The above analysis leads to the conclusion that the shear wave velocity and 
the initial shear modulus can thus be incorporated into the routine design at low cost and using a conventional apparatus.

\section{Acknowledgement}

Project financed by the National Science Centre. Project NN506046740, Decision 0467/B/T02/2011/40.

\section{REFERENCES}

ARULANTHAN R., BOULANGER R.W., RIEMER M.F. 1998: Analysis of bender element tests, Geotechnical Testing Journal (02): 120-131.

BRIGNOLIE., GOTTIM., STOKOEK.H.II., 1996: Measurement of shear waves in laboratory specimens by means of piezoelectric transducers. ASTM Geotechnical Testing Journal 19 (4): 384-397.

HARDIN B.O., BLACK W.L. 1968: Vibration modulus of normally consolidated clay. Journal of the Soil Mechanics and Foundations Division, ASCE 94(2): 353 -368 .

HARDIN,B.O., BLANDFORD G.E. 1989: Elasticity of particulate materials. Journal of the Geotechnical Engineering Division ASCE 115(6): 788-805.

JAMIOLKOWSKI M., LANCELOTTA R., LOPRESTI D.C.F. 1995: Remarks on the stiffness at small strains of six Italian clays. Prefailure Deformation of Geomaterials, Balkema vol. 2: 817-836.

KAWAGUCHI T., MITACHI T., SHIBUYA S. 2001: Evaluation of shear wave travel time in laboratory bender element test. Proceedings of 15th International Conference on Soil Mechanics and Geotechnical Engineering, Istanbul vol. 1: 155-158.

KUWANO R., CONNOLY T.M., JARDINE R.J., 2000: Anisotropic stiffness measurements in a stress-path triaxial cell. Geotechnical Testing Journal, GTJODJ 23 (2): 141-157.
LoPRESTI D.C.F., PALLARA O., JAMIOLKOWSKI M., CAVALLARO A. 1999a: Anisotropy of small stiffness of undisturbed and reconstituted clays. In: Prefailure Deformation of Geomaterials, Jamiolkowski, Lancellotta\&LoPresti (eds), Balkema, Rotterdam: 3-10.

LoPRESTI D.C.F., PALLARA O., JAMIOLKOWSKI M., CAVALLARO A. 1999b: Influence of reconsolidation techniques and strain rate on the stiffness of undisturbed clays from triaxial tests. Geotechnical Testing Journal 22 (3): 211-225.

MARKOWSKA-LECH K. 2006: Estimation of deformation parameters in cohesive soils using seismic tests. $\mathrm{PhD}$ thesis. Department of Geological Engineering, Warsaw University of Life Sciences - SGGW (in Polish).

MARKOWSKA-LECH K., LECH M., SZYMANSKI A. 2007: Estimation of shear modulus from seismic tests on Pliocene clays. Proceedings of the 10th International Symposium on Numerical Models in Geomechanics (NUMOG X), Rhodes, Greece, 25-27.IV.2007: 153-158.

NASH D.F.T., LINGS M.L. PENNINGTON D.S. 1999: The dependence of anisotropic Go shear moduli on void ratio and stress state for reconstituted Gault clay. In. Prefailure Deformation Characteristic of Geomaterial, Jamiolkowski, Lancellotta\&LoPresti (eds), Balkema, Rotterdam: 229-238.

SCHNAID F. 2005: Geo-characterization and properties of natural soils by in situ tests. Proceedings of the 16th International Conference on Soil Mechanics and Geotechnical Engineering, Osaka 2005, Millpress, Rotterdam: 3-45.

STOKOE K.H.II., RATHJE E.M., AXTELL P.J. 2005: Development of an in situ method to measure the nonlinear shear modulus of soil. Proceedings of the 16th International Conference on Soil Mechanics and Geotechnical Engineering, Osaka 2005, Millpress, Rotterdam: 751-754. 
VIGGIANI G. 1995: Recent advances in the interpretation of bender element tests. In: Pre-failure Deformation of Geomaterials, Shibuya, Mitachi\&Miura (eds), Balkema, Rotterdam, vol. 2: 1099-1104.

WOLSKI W., LIPINSKI M.J., 2006: Site characterization for geotechnical and environmental purposes. Proceedings of the XIIIth Danube-European Conference on Geotechnical Engineering, 29-31.V.2006, Ljubljana, vol.1: 129-150.

Streszczenie: Sztywność prekonsolidowanych iłów plioceńskich $w$ zakresie małych odksztatceń. Rozwój infrastruktury technicznej, w tym budowa wysokich budynków, dróg, linii kolejowych i rozbudowy linii metra wymaga danych geotechnicznych dokumentujących zmiany parametrów gruntów występujących w podłożu. Pomiar prędkości fali poprzecznej jest jednym z kluczowych parametrów reprezentującym sztywność podłoża. W niniejszym artykule przedstawione zostały metody i urządzenia mierzące prędkości fali poprzecznej i pozwalające oszacować moduł ścinania gruntu. W artykule przedstawione zostały wyniki badań laboratoryjnych (bender elements) i terenowych (SCPT i SDMT) prekonsolidowanych gruntów spoistych z rejonu Warszawy. Przeprowadzone badania pozwoliły na sformułowanie zależności pomiędzy parametrami mierzonymi w laboratorium a prędkością fali poprzecznej i modułem ścinania. Zaproponowane w artykule zależności zostały poddane weryfikacji w terenie.

Stowa kluczowe: prędkość fali poprzecznej, piezoelementy typu bender, SDMT, SCPT, prekonsolidowane iły

MS. received December 2013

Authors' address:

Wydział Budownictwa i Inżynierii Środowiska SGGW,

Katedra Geoinżynierii

ul. Nowoursynowska 159, 02-776 Warszawa

Poland

e-mail: katarzyna markowska@sggw.pl mariusz_lech@sggw.pl marek_bajda@sggw.pl alojzy_szymanski@sggw.pl 